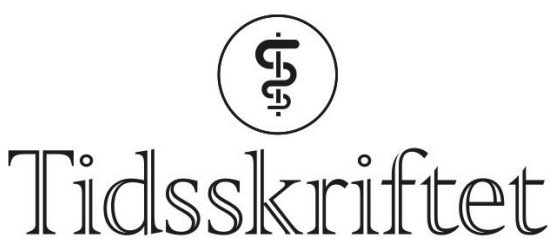

DEN NORSKE LEGEFORENING

\title{
Barn og unge må beskyttes mot energidrikker
}

KRONIKK

\section{KAJA LUND IVERSEN}

Kaja Lund Iversen har mastergrad i samfunnsernæring fra Universitetet i Oslo og er seniorrådgiver i Forbrukerpolitisk avdeling, Forbrukerrådet, der hun arbeider med mat- og ernæringsspørsmål. Forfatter har fylt ut ICMJE-skjemaet og oppgir ingen interessekonflikter.

\section{ERIK ARNESEN}

Erik Arnesen har master i samfunnsernæring, er helsefaglig rådgiver i Landsforeningen for hjerte- og lungesyke, ph.d.-stipendiat ved Universitetet i Oslo og medlem av Nasjonalt råd for ernæring. Forfatter har fylt ut ICMJE-skjemaet og oppgir ingen interessekonflikter.

\section{HELLE MARGRETE MELTZER}

Helle Margrete Meltzer er dr.philos., ernæringsfysiolog og forskningssjef ved Område smittevern, miljø og helse ved Folkehelseinstituttet, og medlem av Nasjonalt råd for ernæring. Forfatter har fylt ut ICMJE-skjemaet og oppgir ingen interessekonflikter.

\section{ANNE LISE BRANTSAETER}

E-post: annelise.brantsaeter@fhi.no Anne Lise Brantsæter er ph.d., klinisk ernæringsfysiolog og seniorforsker ved Folkehelseinstituttet. Hun er medlem av faggruppen for forurensninger, naturlige toksiner og medisinrester i Vitenskapskomiteen for mattrygghet.

Forfatter har fylt ut ICMJE-skjemaet og oppgir ingen interessekonflikter.

Energidrikker er risikoprodukter som ikke bør inngå i barn og unges kosthold. På grunn av skadevirkningene bør salg av energidrikker til barn og unge forbys. 


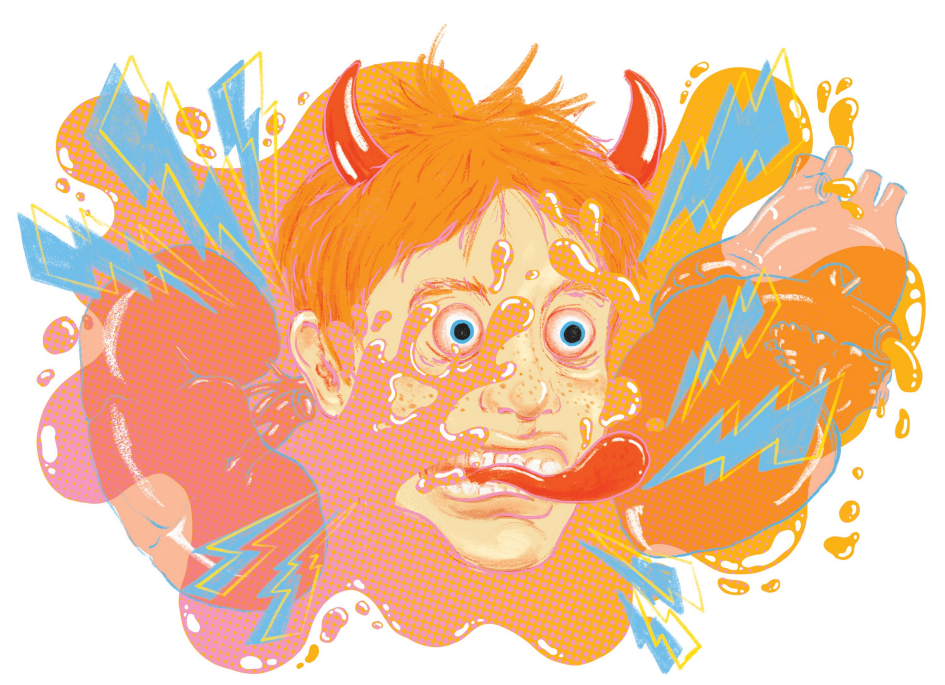

Illustrasjon @ Sylvia Stølan

Omsetningen av koffeinrike energidrikker i Norge nådde nye høyder i juni 2018, med nær 3 millioner liter solgt på én måned, en økning på 400 ooo liter fra mai måned, og over 6o \% $ø$ kning siden juni 2015 (1). Produktene blir mer og mer utbredt blant barn og unge. I aldersgruppene 10-12 år, 13-15 år og 16-18 år oppgir henholdsvis 19\%, 53\% og 70 \% at det hender de drikker energidrikk (2). I 2015 var de tilsvarende andelene $8 \%, 32 \%$ og 62 \% (3). Den raskt $ø$ kende andelen barn og ungdom som drikker energidrikk gir grunn til bekymring (4).

Helse- og omsorgsdepartementet deler denne bekymringen og har bedt Mattilsynet utrede alternative tiltak for å beskytte barn og unge mot helseskader som følge av høyt konsum av energidrikker. Før vi drøfter hvordan helsemyndighetene bør håndtere risikoen som energidrikker utgjør for barn og unge, vil vi redegjøre for skadelige effekter av energidrikkinntak.

\section{Mer enn koffein}

Energidrikker kan best beskrives som industrielt designede leskedrikker som i tillegg til mye koffein (som regel $320 \mathrm{mg} / \mathrm{l}$ eller høyere) inneholder flere stimulerende stoffer (ginseng, guarana, taurin, etc.). Sukker eller søtstoff dekker over smaken av bitre ingredienser som koffein og taurin, hvilket gjør dem lettdrikkelige for barn og unge. I tillegg er de tilsatt B-vitaminer for å fremstå som sunne. Fordi energidrikker inntas som leskedrikk, inneholder flere stimulerende stoffer som virker sammen og kullsyre som øker hastigheten på koffeinopptaket i blodet, er de forbundet med større risiko enn kaffe, selv om kaffe har mer koffein (ca. $500 \mathrm{mg} / \mathrm{l}$ ).

Energidrikker er potente på grunn av deres sammensatte innhold av stimulerende ingredienser. Dette viser blant annet en randomisert, dobbeltblindet, kontrollert overkrysningsstudie der man målte effekt av energidrikk og en koffeinholdig kontrolldrikk, begge med $320 \mathrm{mg} / \mathrm{l} \mathrm{koffein,} \mathrm{på} 18$ friske unge voksne. To timer etter inntak av energidrikk var det signifikant lengre QT-tid, en risikofaktor for fatale hjertearytmier, enn ved inntak av samme mengde koffeindrikk. Begge drikkene medførte økning i systolisk blodtrykk, men seks timer etter inntak var dette signifikant høyere ved inntak av energidrikk enn ved inntak av koffeindrikk (5). Kombinasjonen av koffein og andre stoffer, for eksempel sukker, kan være medvirkende årsak til den alvorlige reaksjonen, men dette har man ikke fullgod kunnskap om ennå. At barn og unge skal ha fri tilgang til avhengighetsdannende produkter som gir $\emptyset$ kt blodtrykk, og i verste fall alvorlige hjerterytmeforstyrrelser, er svært uheldig.

\section{Koffeinforgiftning}

Selv om energidrikker inneholder mer enn koffein, kan vi ikke utelukke risikoene som er knyttet til koffeineksponering. Høyt inntak av koffein på kort tid kan føre til alvorlige 
tilstander som hjertesvikt, hjertearytmi og nyresvikt, tilstander som i verste fall kan føre til død hos sårbare personer. Enkelthendelser av koffeinforgiftning er rapportert i flere land (6). Høyt inntak av energidrikk er også satt i sammenheng med to tilfeller av hjertestans blant ungdom (7). Ungdom med ukjent hjertesykdom kan være mer utsatt for organsvikt. Også i Norge har barn blitt innlagt med alvorlig organsvikt etter å ha drukket store mengder energidrikk på kort tid (8). Vi mener det er en reell risiko for flere tilfeller av alvorlig koffeinforgiftning blant barn og unge som følge av høyt og hurtig forbruk av energidrikk.

\section{Søvnvansker og atferdsproblemer}

Barn og unge har rapportert om uro, irritabilitet, nervøsitet, konsentrasjonsvansker, abstinenssymptomer og andre negative effekter etter inntak av energidrikk (6, 9-11). Koffeindoser på 1,4 mg/kg kroppsvekt kan påvirke innsovning og redusere søvnvarigheten (12). Dette er effekter som over tid kan føre til mer alvorlige atferds- og helseproblemer (6). Hos barn og ungdom som er disponert for angstlidelser, er det dokumentert at koffeinindusert angst også kan inntreffe ved lavt inntak av koffein, det vil si under den «trygge» grensen på 2,5 mg per kg kroppsvekt (9).

Allerede i 2008, før energidrikker ble tillatt i dagligvarehandelen i Norge, ble det anslått at omtrent $20 \%$ av nordiske tenåringer var utsatt for koffeinnivåer fra energidrikk som kunne forårsake angst og uro (10). Barn og ungdom er i en fase av livet hvor mentale lidelser ofte ikke er kjent. Den økende normaliseringen av energidrikker kan potensielt føre til flere tilfeller av koffeinindusert angst blant unge.

Barn og tenåringer som drikker energidrikker, har større sannsynlighet for å bruke alkohol, tobakk eller narkotika (13). Når energidrikk blandes med alkohol, kombineres koffeinets stimulerende egenskaper med alkoholens depressive egenskaper og reduksjon $\mathrm{i}$ atferdskontroll. Kombinasjonen er assosiert med $\emptyset \mathrm{kt} \mathrm{risikoatferd,} \mathrm{helseskade} \mathrm{blant} \mathrm{unge}$ brukere og $\varnothing \mathrm{kt}$ bruk av andre ulovlige stoffer (14). I Norge har 42\% av de i alderen 15-18 år som drikker energidrikk, prøvd å blande energidrikk med alkohol (2).

\section{Avhengighet}

Koffein er et sentralstimulerende stoff som påvirker mange funksjoner i kroppen. Når kroppen blir vant til eksponering, krever den jevnlig tilførsel av det aktuelle stoffet for ikke å få fysisk ubehag (10). Abstinenssymptomer på koffein kan være hodepine, trøtthet, angst, irritasjon og dårlig humør, noe barn og unge også rapporterer. I 2008 ble det anslått at 10 \% av barna med høyest konsum av koffeinholdige drikker, fikk i seg mer koffein enn 2,5 mg per kg kroppsvekt (10). Det er sannsynlig at normalisering av konsum av energidrikker medfører at flere barn og unge utvikler avhengighet, med påfølgende sannsynlighet for abstinenssymptomer knyttet til koffein.

\section{Grense for tolerabelt inntak?}

I Norge frarådes barn og unge å få i seg mer enn 2,5 mg koffein per kg kroppsvekt per dag, uavhengig av kilde (15). Denne verdien blir brukt til å regne om hvor mye energidrikk barn kan eksponeres for uten risiko: Et barn på 30 kg overskrider maksimumsgrensen (75 mg) med en liten boks energidrikk ( $2,5 \mathrm{dl})$, som tilsvarer $80 \mathrm{mg}$. En ungdom på $60 \mathrm{~kg}$ gjør det samme med en halv liter. Det er definitivt flere unge enn tidligere som overskrider anbefalt maksimumsgrense for koffein etter at energidrikkene kom på markedet, og andelen er $ø$ kende.

Det er etter vårt syn svært problematisk å operere med en slik trygghetsgrense, særlig når den blir brukt til å regne ut såkalt trygt inntak av energidrikk. Både europeiske og norske vitenskapskomiteer har konkludert med at det er mange usikkerhetsmomenter knyttet til risikovurderingene av koffein for barn og unge, blant annet fordi det er få studier på disse gruppene $(12,16,17)$. Ifølge et kanadisk ekspertpanel kritiserte enkelte EU-land den 
europeiske risikovurderingen for å ha en for snever tilnærming til helseskade, for å fokusere på koffein heller enn energidrikk og for ikke å være realistisk vedrørende inntaket av energidrikker i kombinasjon med alkohol blant unge (18). Dessuten er skadeeffektene av energidrikker betydelig større enn det som kun kan tillegges koffein.

Norske helsemyndigheter bør ikke sette trygghetsgrense for koffeineksponering hos barn og unge, både fordi data mangler, men aller mest fordi koffein har psykofarmakologiske og sentralstimulerende egenskaper som barn og unge ikke bør utsettes for.

\section{Føre var}

Føre var-prinsippet er grunnleggende i folkehelsearbeidet og bør legges til grunn i risikohåndteringen av energidrikker hos barn og unge (19). Vitenskapelig sikkerhet oppnås først og fremst gjennom randomiserte kontrollerte studier, noe som ikke kan utføres med helseskadelige stoffer. Selv om vi ikke kan gjøre slike studier, vet vi med tilstrekkelig sikkerhet at energidrikk kan gi helseskade hos barn og unge. Det vil derfor være uetisk, et eksperiment med barn og unges helse, $i k k e$ å handle. Manglende sikker kunnskap bør ikke brukes som begrunnelse for å unnlate å treffe tiltak. Utføres tiltak ut ifra føre var-prinsippet, er det opp til produsentene å bevise at det ikke foreligger helsefare $(19,20)$.

\section{Erfaringer fra andre land}

I EU har Litauen (2014) og Latvia (2016) innført forbud mot salg av energidrikker til personer under 18 år. Både i Sverige og Storbritannia pågår det tilsvarende prosesser som i Norge, hvor regulering av salg er blant tiltakene som skal vurderes for å beskytte barn og unge mot helseskade som skyldes konsum av energidrikker.

\section{Forbud mot salg til barn og unge}

Før 2009 var energidrikker regulert som legemidler og forbudt solgt i norsk dagligvarehandel på grunn av det høye koffeininnholdet. Norske myndigheter forsøkte i sin tid å stå imot liberaliseringen fra EU, som førte til frislipp. I dag er det ingenting som hindrer barn og unge i Norge i å anskaffe energidrikker. Tross helsemyndighetenes advarsler til barn og unge, øker inntaket i flere aldersgrupper. Det er godt dokumentert at disse høykoffeinholdige drikkene utgjør et folkehelseproblem, særlig blant barn og unge. Energidrikker er forbundet med betydelig risiko, og har ingen ernæringsmessig nytte. Kunnskapen om uheldige effekter av energidrikk på barn og unges helse og atferd er tilstrekkelig til å innføre inngripende tiltak. Vi mener det er på tide å vurdere forbud mot salg av energidrikker til barn under 18 år.

\section{LITTERATUR:}

1. Bryggeri- og drikkevareforeningen. Salgstall. Omsetning av energidrikker totalt. http://www.drikkeglede.no/tall_og_fakta/?PT_Radnr=5\&mnd=5\&aar=2018 (6.7.2018).

2. Energidrikk, barn og unge. Undersøkelse om bruk av energidrikker blant barn og unge 2018. Oslo: Forbrukerrådet, 2018.

https://fil.forbrukerradet.no/wp-content/uploads/2018/o8/rapport-2018-energidrikk-barn-ogunge.pdf(3.9.2018).

3. Undersøkelse om bruk av energidrikker blant barn og unge. Oslo: Forbrukerrådet, 2015. https://fil.forbrukerradet.no/wp-content/uploads/2015/12/Rapport_10-18_aar_energidrikker_endelig.p df(6.7.2018).

4. Breda JJ, Whiting SH, Encarnação R et al. Energy drink consumption in europe: a review of the risks, adverse health effects, and policy options to respond. Front Public Health 2014; 2: 134.

[PubMed][CrossRef]

5. Fletcher EA, Lacey CS, Aaron M et al. Randomized controlled trial of high-volume energy drink 
versus caffeine consumption on ECG and hemodynamic parameters. J Am Heart Assoc 2017; 6: eoo4448. [PubMed][CrossRef]

6. Seifert SM, Schaechter JL, Hershorin ER et al. Health effects of energy drinks on children, adolescents, and young adults. Pediatrics 2011; 127: 511 - 28. [PubMed][CrossRef]

7. Enriquez A, Frankel DS. Arrhythmogenic effects of energy drinks. J Cardiovasc Electrophysiol 2017; 28: 711 - 7. [PubMed][CrossRef]

8. Moe E, Holø RM. Henrik (14) var døden nær - leger tror energidrikk er årsaken. NRK 19.3.2018. https://www.nrk.no/ho/tror-energidrikk-forte-til-kollaps-1.11555356 (13.7.2018).

9. Wikoff D, Welsh BT, Henderson R et al. Systematic review of the potential adverse effects of caffeine consumption in healthy adults, pregnant women, adolescents, and children. Food Chem Toxicol 2017; 109: $585-648$. [PubMed][CrossRef]

10. Meltzer HM, Fotland T $\varnothing$, Alexander J et al. Risk assessment of caffeine among children and adolescents in the Nordic countries. København: Nordic Council of Ministers, 2008.

11. Hammond D, Reid JL, Zukowski S. Adverse effects of caffeinated energy drinks among youth and young adults in Canada: a Web-based survey. CMAJ Open 2018; 6: E19 - 25. [PubMed][CrossRef]

12. Vitenskapskomiteen for mat og miljø. Koffein i energidrikker og kosttilskudd.

https://vkm.no/risikovurderinger/allevurderinger/andrestoffer/koffeinienergidrikkerogkosttilskudd. 4.761cdo4215dabef8age84616.html (6.7.2018).

13. Visram S, Cheetham M, Riby DM et al. Consumption of energy drinks by children and young people: a rapid review examining evidence of physical effects and consumer attitudes. BMJ Open 2016; 6: e01038o. [PubMed][CrossRef]

14. Wolk BJ, Ganetsky M, Babu KM. Toxicity of energy drinks. Curr Opin Pediatr 2012; 24: 243 - 51. [PubMed][CrossRef]

15. Matportalen.no. Vær oppmerksom på hvor mye koffein barn og ungdom får i seg. http://www.matportalen.no/rad_til_spesielle_grupper/tema/barn/vaer_oppmerksom_paa_hvor_my e_koffein_barn_og_ungdom_faar_i_seg(6.7.2018).

16. Vitenskapskomiteen for mat og miljø. Oppdatert risikovurdering av ingredienser i "energidrikker”. https://vkm.no/risikovurderinger/allevurderinger/oppdatertrisikovurderingavingredienserienergidri kker.4.2994e95b15cc54507163523c.html (6.7.2018).

17. EFSA Panel on Dietetic Products, Nutrition and Allergies.. Scientific opinion on the safety of caffeine. EFSA J 2015; 13: 4102.

18. Caffeinated energy drinks. Technical report on public health concerns and regulation in Canada. Toronto: Toronto Public Health, 2017.

https://www.toronto.ca/legdocs/mmis/2017/hl/bgrd/backgroundfile-101646.pdf(6.7.2018).

19. Martuzzi M, Tickner JA. The precautionary principle: protecting public health, the environment and the future of our children. København: WHO Regional Office for Europe, 2004. http://www.euro.who.int/_data/assets/pdf_file/ooo3/91173/E83079.pdf(6.8.2018).

20. The precautionary principle. https://eur-lex.europa.eu/legal-content/EN/TXT/HTML/?uriLEGISSUM:132042\&fromEN (21.6.2018).

Publisert: 17. september 2018. Tidsskr Nor Legeforen. DOI: 10.4045/tidsskr.18.0585

Mottatt 20.7.2018, første revisjon innsendt 31.7.2018, godkjent 6.8.2018.

(C) Tidsskrift for Den norske legeforening 2020. Lastet ned fra tidsskriftet.no 